\title{
SELECTION OF FOOD WASTE MANAGEMENT OPTION BY PROMETHEE METHOD
}

\section{Olgica Erceg}

Professional paper / Stručni rad

University of Split, Faculty of Civil Engineering, Architecture and Geodesy, Doctoral student Jure Margeta

University of Split, Faculty of Civil Engineering, Architecture and Geodesy, Full Professor

Corresponding author: margeta@gradst.hr

\begin{abstract}
Food waste management performed following the EU Circular Economy Strategy principles poses a problem in small islands. There are several standard food waste management methods on islands; however, there are two specific methods which must be considered along with their positive and negative impacts. These two specific methods are discharging food waste into the city's sewer system and transporting waste to the mainland, i.e., to regional waste processing facilities. This paper presents a mult-criteria decision analysis to evaluate different waste management options and their applicability in small islands such as Vis. The results of this study indicate that the best food waste treatment option for small islands is discharging food waste into the city's sewer system to be processed with wastewater through wastewater treatment. The PROMETHEE method used in this study has proved to be a useful tool for solving the food waste management problem.
\end{abstract}

Keywords: multi-criteria decision analysis; PROMETHEE method; food-waste management; small island; circular economy

\section{ODABIR OPCIJE UPRAVLJANJA OTPADOM HRANE METODOM PROMETHEE}

Sažetak: Rješavanje problema otpada hrane u skladu sa strategijom kružnog gospodarstva je složen problem na malim otocima. Postoji nekoliko standardnih postupaka za rješavanje problema, ali i dva specifična, koja je nužno uzeti u obzir. Jedan je ispuštanje usitnjenog otpada hrane u kanalizacijski sustav, a drugi je transport otpada na kopno, u regionalni centar. Svaki postupak ima svoje prednosti i nedostatke u odnosu na cilj rješavanja problema. Problem se stoga mora rješavati cjelovito, sustavnim pristupom, a izbor prihvatjjivog rješenja primjenom višekriterijskog postupka. U ovome je radu takav postupak primijenjen za rješavanje problema na primjeru otoka Visa. Dobiveni rezultat pokazuju da je rješenje $s$ ispuštanjem otpada hrane u lokalni kanalizacijski sustav najprihvatjjivije te da u cijelosti zadovoljava ciljeve kružnog gospodarstva. Korištenje metode PROMETHEE za izbor optimalne opcije pokazalo se vrlo praktičnim i korisnim.

Ključne riječi: višekriterijska analiza; PROMETHEE; gospodarenje otpadom hrane; mali otoci; kružno gospodarstvo 


\section{INTRODUCTION}

The subject of this paper is the optimization of kitchen/food waste management on the island of Vis following the Circular Economy Action Plan. A circular economy is a model of production and consumption that involves sharing, borrowing, reusing, repairing, restoring, and recycling existing products and materials for as long as possible to extend the products' value. The EU Circular Economy package [1], i.e., the Circular Economy Action Plan provides for $65 \%$ waste reduction until 2035 , conversion of waste into resources, cessation of waste disposal in landfill sites by 2030 , and energy recovery, which includes waste-to-energy generation and the use of biofuels. The generated waste should be treated and disposed of in accordance with the waste hierarchy [2]. The food waste management hierarchy is similar to the hierarchy defined in the Waste Framework Directive [2] (WFD) (Figure 1). Food waste should be prevented, re-used whenever possible, recycled into animal feed or via composting to produce plant fertilizer, and recovered by anaerobic digestion to produce biogas as an energy resource. At the end of the hierarchy, the unavoidable waste should be disposed of using landfill biogas utilization [3].

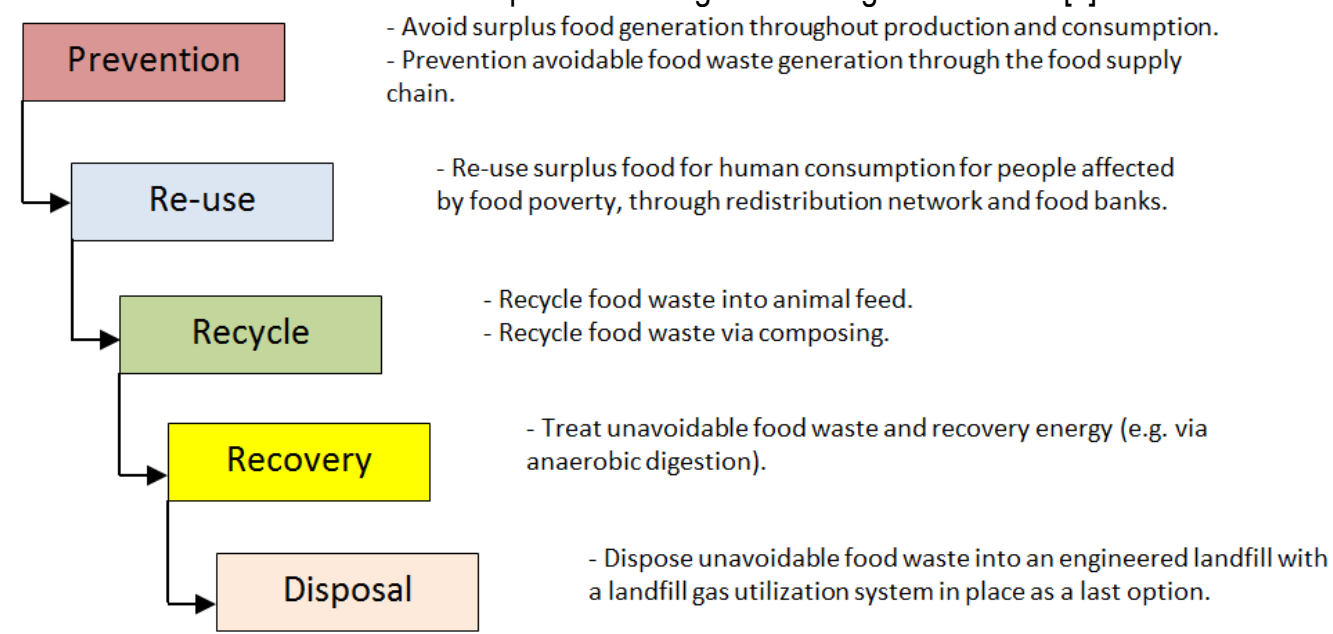

Figure 1 Interpretation of the waste hierarchy for food waste [2]

Regarding environmental protection, the waste treatment processes have different impacts on climate change, the amount of nutrients provided and their reuse, primary energy use, the ozone layer, and other concerns. Therefore, it is advisable to determine the net effect of these processes on the environment by applying life cycle analysis [4]. Likewise, economic efficiency is significantly different for each process, and the unit price for treated waste (euro/kg) depends heavily on the facility's capacity. Storage of food waste prior to treatment and storage of waste treatment products (compost, sludge, energy, gas, and heat) have a significant impact on overall system efficiency. These are all important technological characteristics of the process that should be considered when selecting a solution [5].

The generation of food waste results in environmental pollution and resource, energy, and/or nutrient loss. The storage, collection, transportation, and transfer of wet and rapidly decomposable waste are complex tasks, requiring the use of specialized technology to decrease adverse environmental effects. The entire collection and transport system uses sealed containers to prevent contact with animals and to control gas and wastewater discharge into urban environments. If waste is stored for an extended period in one location, the rate of decomposition decreases, resulting in a decrease in gas production and wastewater generation; furthermore, the waste often requires drying or the addition of certain substances. Therefore, it is best to separate the food waste at the source prevent wastage during collection, transport, and preliminary treatment.

A system in which ground organic kitchen waste and food are directly discharged into the sewerage system is also used [6]. Such a system has been used extensively in the USA and to a lesser degree in the EU. Such a system does not require local storage and transport and has specific advantages and drawbacks [7].

The worst management option is mixing organic waste with other municipal waste types because it reduces the value of the other types of waste. This entire process is more expensive than a separate treatment.

Erceg, O, Margeta, J 
This complex problem must be addressed by a system analysis methodology that respects the environmental, economic, social, and technical objectives of the island of Vis equally [8]. This methodology uses the concepts of mult-objective optimization and Pareto optimality to help identify the most sustainable management options for food waste in Vis, intending to minimize environmental and economic impacts and maximize social impacts [9]. Optimization can be realized using various methods [10]. Multi-objective optimization has been used for a long time to solve solid waste management problems $[8,9,11]$ and has provided reliable results. Therefore, this method was considered relevant for solving the issues surrounding food-waste management on small islands. The top five methods, SAW, AHP, TOPSIS, PROMETHEE, and ELECTRE, are used in solid waste management [11]. This paper presents the application of the Preference Ranking Organization Method for Enrichment Evaluations (PROMETHEE) method as the optimal food waste management solution for Vis Island [12]. This method is one of the outranking methods. Compared with other multi-criteria evaluation methods, the outranking methods allow for the incomparability between technologically different alternatives, such as the one discussed in the current study. The model is easily accessible with quality instructions for its use and the interpretation of results. In Croatia, there has been extensive experience of using this method, and its application has justified the expectations. The available computer package provides a clear graphical presentation of the order of alternatives and an interactive analysis of the order's sensitivity against the magnitudes of the weight values. Therefore, it was most practical to use this method. Other outranking methods could be used, and the same results would be obtained. The multicriteria methods, or the PROMETHEE method, have not been used previously to solve the problem of food waste management on the islands.

\section{WASTE GENERATION AND CHARACTERISTICS OF VIS ISLAND}

The case study presented in this paper refers to the island of Vis (Figure 2). Vis is a small inhabited island in Croatia $\left(45.61 \mathrm{~km}^{2}\right)$, located in the middle of the Adriatic Sea, approximately $50 \mathrm{~km}$ from the coast. It is a typical karst island with an indented coastine and a rich karst relief. The island's Mediterranean climate is characterized by cold, humid winters and dry, hot summers. The average annual rainfall is $800 \mathrm{~mm} / \mathrm{m}^{2}$, and the average temperature is $16{ }^{\circ} \mathrm{C}$. Due to the extremely permeable karst geological structure, the surface water quickly infiltrates into the groundwater, where it forms an aquifer in contact with the sea. This aquifer is used for water supply for the island. More than $90 \%$ of the population is connected to the municipal water supply system.

The island has 11 small settlements and many cottages scattered along the coast (Figure 2). Most of the population lives in two smaller settlements, Vis and Komiža, located on opposite sides of the island, with Vis to the northeast and Komiža in the southwest. The island of Vis belongs to Split-Dalmatia County, and there are two units of local self-government: the city of Vis and the city of Komiža. According to the population census in 2011, the city of Vis had 1934 inhabitants, while the city of Komiža had a population of 1526 . The main activities comprise the tourism industry, agriculture, and fishing. The number of tourists and overnight stays has been steadily increasing, recording 352088 overnight stays in 2016.

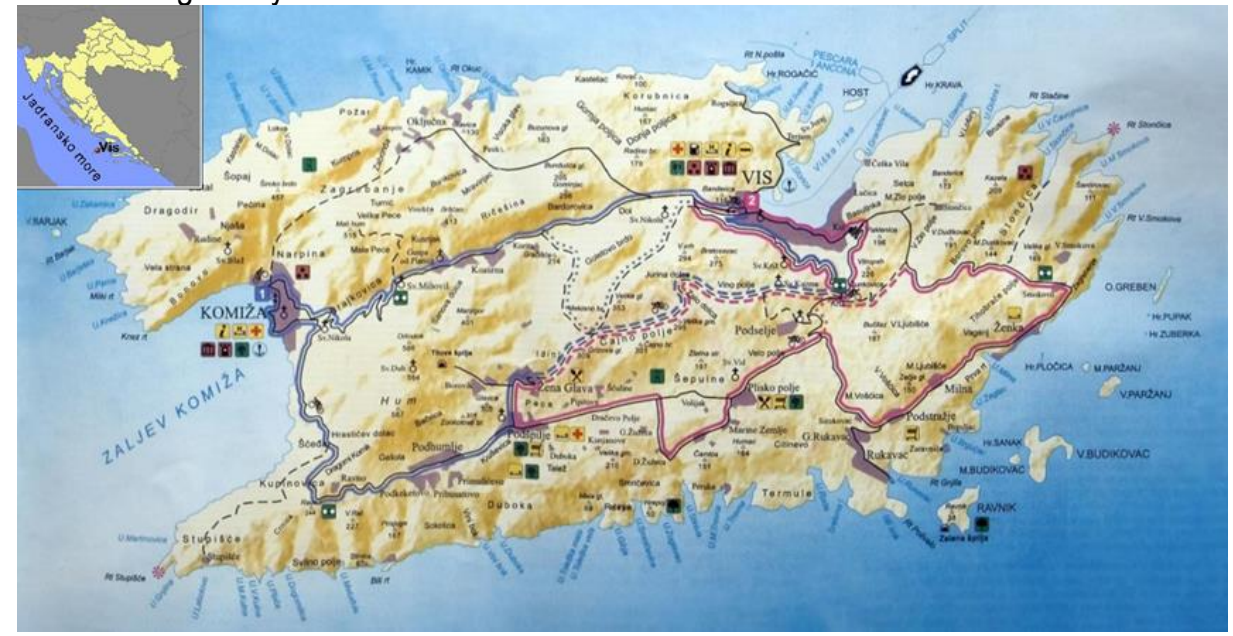

Figure 2 Vis Island

Erceg, O, Margeta, J 
The Gradina d.o.o. Utility Company manages waste collection and disposal. The main generators of solid waste are the residents, tourists, and the hospitality industry. Currenty, the collected waste is mixed and disposed of in two local landfills. The strategy and action plan for the management of waste in Croatia had the objective of transporting the entire waste from the island of Vis to the mainland, i.e., to regional waste management centers in Lećevica. The larger settlements Vis and Komiža have a sewerage system and a mechanical wastewater treatment plant (preliminary level of treatment). Less than $50 \%$ of the population has access to the sewerage system. Under the sewerage system development plan, two sewerage systems and two wastewater treatment plants (WWTPs) with primary treatment levels will be constructed on the island for Vis and Komiža.

The amount of waste generated in 2016 was $1658 \mathrm{ta}$, (data from the local waste management company Gradina Vis d.o.o.) [13]. The projected amount of waste for 2030 is based on the population growth rate of $0.3 \%$ and a $1 \%$ growth in overnight stays, resulting in $0.9 \mathrm{~kg} /$ day/capita and $1.2 \mathrm{~kg} /$ day/overnight stay, respectively (Figure 3). The seasonal balance is presented in Table 1.

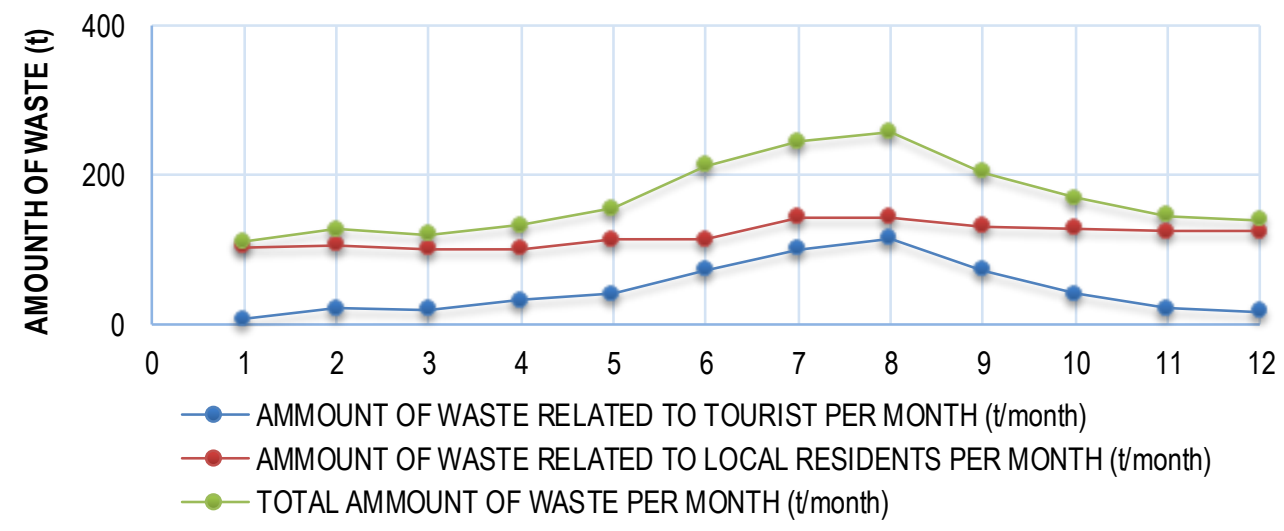

Figure 3 The projected monthly generated waste in 2030

The composition of municipal waste has not been tested, and literature data were used for the analysis (Table 1) [14]. The current study focused on food waste disposal. Kitchen waste accounts for $41 \%$ of total household waste. The average annual quantity of food/kitchen waste generated per day amounts to 2.3 (t/day); furthermore, the average quantity during winter is 1.88 (t/day), and during summer, 3.14 (t/day). The estimated annual quantities of waste are $828.2 \mathrm{ta}$. These are significant quantities that must be managed according to the policy defined by the Circular Economy.

Table 1 The projected amounts of waste during high season and off-season for 2030

\begin{tabular}{|c|c|c|c|c|c|c|c|c|}
\hline \multirow[b]{2}{*}{ Types of waste } & \multirow[b]{2}{*}{$\%$} & \multirow[b]{2}{*}{ Total t/a } & \multicolumn{3}{|c|}{ Off-season $(1,102 t)$} & \multicolumn{3}{|c|}{ During high season $(918 \mathrm{t})$} \\
\hline & & & $\begin{array}{l}\text { Average } \\
\text { amount } \\
\text { (t/day) }\end{array}$ & $\begin{array}{l}\text { Average } \\
\text { amount } \\
\text { (t/month) }\end{array}$ & $\begin{array}{l}\text { Amount } \\
\text { (t/a off- } \\
\text { season) }\end{array}$ & $\begin{array}{c}\text { Average } \\
\text { amount } \\
\text { (t/day) }\end{array}$ & $\begin{array}{l}\text { Average } \\
\text { amount } \\
\text { (t/month) }\end{array}$ & $\begin{array}{l}\text { Amount } \\
\text { (t/a high } \\
\text { season) }\end{array}$ \\
\hline Kitchen waste & 41.0 & 828.2 & 1.88 & 56.48 & 451.8 & 3.14 & 94.1 & 376.3 \\
\hline Paper and cardboard & 20.3 & 410.1 & 0.93 & 27.96 & 223.7 & 1.55 & 46.5 & 186.3 \\
\hline Skin and bones & 3.1 & 62.6 & 0.14 & 4.27 & 34.2 & 0.24 & 7.1 & 28.4 \\
\hline Wood & 1.2 & 24.2 & 0.06 & 1.65 & 13.2 & 0.1 & 2.7 & 11.0 \\
\hline Textile & 8.2 & 165.6 & 0.38 & 11.3 & 90.7 & 0.63 & 18.8 & 75.2 \\
\hline Glass & 7.0 & 141.4 & 0.32 & 9.64 & 77.1 & 0.54 & 16.1 & 64.2 \\
\hline Metals & 4.1 & 82.8 & 0.19 & 5.65 & 45.2 & 0.31 & 9.4 & 37.6 \\
\hline Inert & 1.5 & 30.3 & 0.07 & 2.07 & 16.5 & 0.11 & 3.4 & 13.7 \\
\hline Plastics & 11.6 & 234.3 & 0.53 & 15.98 & 127.8 & 0.89 & 26.6 & 106.4 \\
\hline Natural rubber & 0.9 & 18.2 & 0.04 & 1.24 & 9.9 & 0.07 & 2.1 & 8.3 \\
\hline Special & 0.4 & 8.1 & 0.02 & 0.55 & 4.4 & 0.03 & 0.9 & 3.7 \\
\hline
\end{tabular}

Erceg, O, Margeta, J 
Glass, paper, cardboard, plastics, metal, clothing, and footwear needs to be collected separately. These are dry components of municipal waste that can be stored easily and for extended periods without adverse environmental impacts. Their volume is reduced by compaction at the source or after collection; additionally, they are baled or packaged for efficient storage and transport. When sufficient quantities are accumulated, the waste is transported to the mainland for further processing and sales. This process is typical for managing segregated dry municipal waste following the Circular Economy Action Plan and guidelines. Therefore, it can be concluded that the issue of dry waste has been resolved.

When the generated waste is mixed, the separation of waste on the island or transport of mixed waste to the mainland should be organized. In principle, this solution is less acceptable environmentally and economically than the source separation of waste and is, therefore, not recommended. The waste management plan in Croatia recommends that source separation is the best solution [15]. Transport to the mainland is expensive because it requires long-distance transport and the use of a ferry, which results in the emission of greenhouse gases and other negative impacts.

The objective of managing organic waste (wetkitchen and dry/yard waste) locally on the island of Vis is to achieve local and global environmental security and a sustainable livelihood. This objective includes the realization of an organic waste management strategy through the most efficient, cheapest, and environmentally and socially acceptable waste treatment technology.

\section{POSSIBLE OPTIONS AND THEIR CHARACTERISTICS}

There are two basic strategic options: (i) local organic waste management, or (ii) organic waste management on the mainland with regional management. Local management implies that all organic waste can be collected and transported daily. Regional management includes local collection, storage, occasional ferry transport to the mainland, subsequent truck transport to the collection center, and treatment with the regional center's technology. Regional transport requires local storage and local treatment of the collected waste to slow down the decomposition process. The transport of organic waste must be adapted for such types of cargo (wet/muddy material that decomposes and generates toxic and flammable gases). It is assumed that the treatment of organic waste on the mainland will be carried out using anaerobic technology.

Three basic alternatives for the treatment of waste have been adopted for local management on the island: (i) the classical biological processes; (ii) kitchen waste disposed of via the sewer (the wet process), and (iii) thermal process (incineration). The thermal process alternative is not realistic due to the relatively small amount of waste [14]. Additionally, the Circular Economy guidelines consider using energy to eliminate bio-waste as the last acceptable option. Therefore, incinerating the food waste was excluded from the analysis. The following local alternatives were further analyzed: composting, anaerobic digestion, and the wet process.

The use of food waste disposers in kitchen sinks has several possible sub-variants for ground wet organic waste collection: (i) directly by sewage to the local municipal WWTP, (ii) by a vacuum system into a container and occasional transport to the nearest sewerage system, and (iii) by local collection and storage in containers, from which the fluid is discharged into the sewer, and the sludge is transported by tankers to the local or regional sludge treatment plant.

The collection method depends on the development and availability of the sewerage system and treatment plant. For Vis Island, by 2023, a sewerage system and a suitable plant for the cities of Vis and Komiža will be built, and most of the houses will be connected to the system $(>80 \%)$. Other isolated housing units will use septic or holding tanks, which will be managed, possibly by discharging the tanks into the local municipal wastewater treatment facilities. Therefore, it is not realistic to build vacuum systems. It is assumed that after grinding, the kitchen waste will be transported either from local septic tanks or through the municipal sewerage system to the WWTP. This solution is simple and reliable with the least adverse environmental impact and was, therefore, adopted for further analysis.

Kitchen bio-waste generates approximately $0.25 \mathrm{PE}$ of BOD5 (PE=60 g BOD $/ \mathrm{d})$ [15], indicating that the discharge of kitchen waste into the sewer will increase the capacity of the plant by $25 \%$. The long-term capacity of the plant is approximately $3000 \mathrm{PE}$. The increase of $25 \%$ (3 $750 \mathrm{PE}$ ) will not exceed threshold $10000 \mathrm{PE}$; hence, the construction of a plant with a higher level of treatment will not be required (secondary level of treatment) [2]. Ultimately, the organic kitchen waste will be processed with the primary sludge separated at the municipal plant.

Erceg, O, Margeta, J 
The nitrate-rich sludge from the discharged food waste could be obtained from the treatment plant and be used as a fertilizer in agriculture after further processing [7]. This option is promising, but other options must be considered when making the final decision.

Classical biological methods of anaerobic digestion and composting were also evaluated for local solutions $[14,16]$. Each system consists of the following elements: (i) storage at source; (ii) storage outside the housing facilities, collection, and transportation of the waste, including transfer stations if necessary; (iii) processing and using the waste. The impacts for each alternative have been assessed, and the values of the criteria are defined in Table 2. These data were obtained by appropriate estimations, from literature data, and expert evaluations based on input data (Table 1), technology characteristics, and cost [13], as well as the environmental and social characteristics of the island. Because of a small number of users and the distance from the system, one solution was the local collection in paper bags and disposal in special containers outside the residential area, with daily waste collection. A facility for slowing down the decomposition process is not envisaged due to the short-term waste retention period (less than 24 hours).

Only one organic waste treatment facility was forecasted for the entire island. The study considered outdoor static pile composting (OC), indoor composting with forced aeration (IC), and an anaerobic digester with high concentration of solids (AD) [14]. Composting is a simple, cheap, and reliable technology for the decomposition of organic matter, which is a natural phenomenon in the environment. The compost generated can be used as a natural fertilizer for organic farming, keeping produce free of chemicals. The main challenges are gaseous emissions (greenhouse gases, ammonia, and volatile organic compounds) and non-biodegradable impurities. AD is the most widely employed method for WWTP sludge treatment. The goal is to reduce the amount of sludge that needs disposal. Approximately half of the sludge is converted into gases $\left(\mathrm{CO}_{2}\right.$ and $\left.\mathrm{CH}_{4}\right)$, while the remainder is dried and becomes a residual, soil-like material that can be composted. The capital and operating cost are high, especially for small units. This technology is rarely used in WWTPs smaller than 5,000 PE [16].

The characteristics, advantages, and disadvantages of the selected technologies were identified primarily with data from literature [6-9,11], taking into account the local characteristics, climate, and the amount of waste. Five realistic options were analyzed for the island of Vis, considering these factors. The determined values of each criterion are given in Table 2.

\section{SELECTION OF THE SOLUTION}

\subsection{Methodology}

Four aspects of the solutions' sustainability were evaluated: technological, economic, ecological, and social. Stakeholders and decision-makers often have divergent views, especially in the environmental and social sectors. The PROMETHEE method was used to combine the traditional technical criteria with environmental, social, and economic standards to integrate this divergence. The respective criteria were selected for each aspect. The options considered in this study have not been analyzed previously as a solution for managing food waste on small islands. Therefore, the standard sustainability criteria were adapted to the features of the options considered for Vis Island. The criteria were grouped into standard groups of sustainability criteria (Table 2). Within each group, several subcriteria were selected that comprehensively describe the problem being solved and are commonly used to solve such problems $[6-9,11]$. A total of 21 indicators were used in this study. One part of the criteria was numerically defined, while the other portion was defined qualitatively by using a scale of $1-6$. In solving such problems, it is always a great challenge to choose the satisfactory criteria. The criteria selected for this study reflect the essential characteristics of the problem being solved. Similar criteria have already been used for comparable problems [6-9, 11]. The selected criteria fully correspond to the stakeholders' concerns, the island's natural and socioeconomic characteristics, and the traits of the management options [5-7]. From the data obtained (Table 2), it is clear that the "wet process" option is very favorable. Although this solution is promising, it cannot be adopted without a full analysis of the other viable options. This analysis is especially critical because such an option has not been used in Croatia. The risk to decision-makers is too great, and all options should be evaluated by a standard mult-criteria analysis.

The choice of relative weight $(w)$ is an important element in the multi-criteria analysis. The various stakeholder groups have different preferences in the individual criteria groups; therefore, it is difficult to achieve a consensus.

Erceg, O, Margeta, J 
Several methods can be used to determine the weight. In this study, a simplified approach was used in which the opinions of individual stakeholder groups and experts were used. The final values were determined by the "rankorder weighting method" and the process of pairwise comparison. In this method, the weights are distributed as:

$\mathrm{w}_{1} \geq \mathrm{w}_{2} \geq \mathrm{w}_{3} \geq \ldots \geq \mathrm{w}_{\mathrm{n}} \geq 0 ; \sum_{i=1}^{n} w_{i}=1$

(1)

Weight coefficients were assigned to each group of criteria based on the opinions of stakeholders and experts by performing a simplified pairwise comparison. Finally, the percentage of preferences were assigned to each set of criteria (economic $23 \%(0.23)$, environmental $25 \%(0.25)$, social and local $15 \%(0.15)$, wider/external $15 \%(0.15)$, and technical-technological $22 \%(0.22))$, which have been subsequently distributed to individual criterion according to the number of criteria in each group. These preferences were selected based on expert's experience from other similar projects and consultation with local stakeholders:

$w_{i}^{m}=w_{i} / m$, where $m$ is the number of criteria in the group $w_{i}$

The features of PROMETHEE method are described thoroughly in previous literature [17-19] and will not be widely presented in this paper. However, the PROMETHEE method has never been applied to the choice of food waste management solutions on islands. The PROMETHEE I method provides a partial ranking of actions. The full ranking can be produced under the PROMETHEE II method, if necessary. The mult-criteria preference index for a pair of alternatives Ai and Ak is defined as:

$$
\pi\left(A_{i}, A_{k}\right)=\frac{\sum_{j=1}^{n} p_{j} w_{j}\left(A_{i} A_{k}\right)}{\sum_{j=1}^{n} w_{j}}
$$

where $p_{j}(a, b)$ is the preference function for alternatives $a$ and $b$. The income flow is calculated as:

$$
\Phi^{+}\left(A_{i}\right)=\sum_{k=1}^{m} \pi\left(A_{i}, A_{k}\right) \quad k=1,2, . ., m
$$

and the outgoing flow is calculated as:

$$
\Phi^{-}\left(A_{i}\right)=\sum_{k=1}^{m} \pi\left(A_{i}, A_{k}\right) \quad k=1,2, . ., m
$$

Finally, the net flow is equal to the difference between the incoming flow and outgoing flow. After obtaining all the net flow alternatives, the alternative having the maximum net flow was considered as the best solution. The multi-criteria analysis was performed using the software package Visual PROMETHEE Academic Edition 1.4.๑ [12]. The available software package is user-friendly, has a high-quality graphical interpretation of the results and order of options, and enables an efficient sensitivity analysis of the order of options regarding the criteria's values and weights.

Table 2 The input data OPTIONS 
Selection of food waste managementoption by PROMETHEE method

\begin{tabular}{|c|c|c|c|c|c|c|c|c|}
\hline Criteria & Indicators & $\begin{array}{l}\text { Outdoor } \\
\text { composting }\end{array}$ & $\begin{array}{l}\text { Indoor } \\
\text { composting }\end{array}$ & $\begin{array}{l}\text { Anaerobic } \\
\text { digestion }\end{array}$ & $\begin{array}{l}\text { Wet } \\
\text { process }\end{array}$ & $\begin{array}{l}\text { Transportatio } \\
\mathrm{n} \text { to the } \\
\text { mainland }\end{array}$ & $\begin{array}{l}\text { Weight } \\
\text { coefficient }\end{array}$ & $\begin{array}{l}\operatorname{Min} / \\
\max \end{array}$ \\
\hline \multirow[t]{4}{*}{$\begin{array}{l}\text { THE ECONOMY } \\
\text { ASPECT } 23 \%\end{array}$} & $\begin{array}{l}\text { Cost authority for } \\
\text { waste treatment } € / t\end{array}$ & 45.0 & 60.0 & 55.0 & 45.0 & 55.0 & 6.00 & $\min$ \\
\hline & Costs of fuel $1 / t$ & 1.5 & 1.5 & 1.5 & 0.1 & 6.0 & 5.00 & $\min$ \\
\hline & $\begin{array}{l}\text { Cost for society of } \\
\text { waste treatment } € / t\end{array}$ & 45.0 & 60.0 & 80.0 & 55.0 & 85.0 & 6.00 & $\min$ \\
\hline & $\begin{array}{l}\text { Cost of collection } \\
\text { and transport }\end{array}$ & 105.0 & 105.0 & 105.0 & 10.0 & 150.0 & 6.00 & $\min$ \\
\hline \multirow{8}{*}{$\begin{array}{l}\text { THE ENVIRONMENTAL } \\
\text { ASPECT } 25 \%\end{array}$} & Environmental load & 4.0 & 5.0 & 6.0 & 6.0 & 3.0 & 5.00 & $\max$ \\
\hline & Odor & 2.0 & 4.0 & 5.0 & 5.0 & 4.0 & 2.50 & $\max$ \\
\hline & Noise & 4.0 & 5.0 & 4.0 & 4.0 & 3.0 & 2.50 & $\max$ \\
\hline & Traffic & 3.0 & 4.0 & 3.0 & 4.0 & 3.0 & 2.50 & $\max$ \\
\hline & $\begin{array}{l}\text { Visual and } \\
\text { landscape impact }\end{array}$ & 1.0 & 2.0 & 3.0 & 4.0 & 3.0 & 4.00 & $\max$ \\
\hline & $\begin{array}{l}\text { Time/space for } \\
\text { home waste }\end{array}$ & 5.0 & 5.0 & 5.0 & 6.0 & 5.0 & 2.00 & $\max$ \\
\hline & $\begin{array}{l}\% \text { of work force } \\
\text { hired locally }\end{array}$ & 90.0 & 80.0 & 80.0 & 30.0 & 30.0 & 2.00 & $\max$ \\
\hline & $\begin{array}{l}\mathrm{CO}_{2} / \mathrm{t} \text { emission of } \\
\text { processed waste }\end{array}$ & 600.0 & 400.0 & 100.0 & 100.0 & 100.0 & 4.50 & $\min$ \\
\hline \multirow[t]{3}{*}{$\begin{array}{l}\text { THE LOCAL SOCIAL } \\
\text { ASPECT } 15 \%\end{array}$} & $\begin{array}{l}\text { Accident rate of } \\
\text { workplace }\end{array}$ & 1.0 & 1.0 & 2.0 & 1.0 & 2.0 & 5.50 & $\min$ \\
\hline & Occupational risks & 3.0 & 2.0 & 3.0 & 5.0 & 3.0 & 5.50 & $\max$ \\
\hline & Labor intensity & 2.0 & 3.0 & 4.0 & 5.0 & 4.0 & 4.0 & $\max$ \\
\hline \multirow[t]{2}{*}{$\begin{array}{l}\text { THE WIDER SOCIAL } \\
\text { ASPECT } 15 \%\end{array}$} & $\begin{array}{l}\text { Green job per } € \\
\text { invested }\end{array}$ & 2.0 & 2.0 & 3.0 & 4.0 & 4.0 & 7.50 & $\max$ \\
\hline & $\begin{array}{l}\text { Tech innovation in } \\
\text { treatment over time }\end{array}$ & 3.0 & 5.0 & 1.0 & 4.0 & 1.0 & 7.50 & $\max$ \\
\hline \multirow{4}{*}{$\begin{array}{l}\text { THE TECHNOLOGICAL } \\
\text { ASPECT } 22 \%\end{array}$} & Efficiency & 3.0 & 3.5 & 5.0 & 5.0 & 4.5 & 6.00 & $\max$ \\
\hline & Safety & 5.0 & 5.0 & 3.0 & 5.0 & 3.0 & 7.00 & $\max$ \\
\hline & Reliability & 5.0 & 5.0 & 4.5 & 5.0 & 3.0 & 6.00 & $\max$ \\
\hline & Maturity & 5.5 & 5.0 & 4.5 & 4.5 & 3.5 & 3.00 & $\max$ \\
\hline
\end{tabular}

\subsection{Results}

PROMETHEE Flow Table

The results are shown in Table 3. The most acceptable solution is the wet process, followed by indoor composting, outdoor composting, anaerobic digestion, and, ultimately, transportation to the mainland. The criteria values and weights clearly defined a firm rank-order of alternatives. The main principles of the formation of modern eco-oriented architecture objects were identified:

Table 3 The results obtained - PROMETHEE Flow Table

\begin{tabular}{|c|c|c|c|c|}
\hline Rank & TECHNOLOGY & Phi & Phit & Phi- \\
\hline 1 & WET PROCESS & 0.6763 & 0.7312 & 0.0550 \\
\hline 2 & INDOOR COMPOST ING & -0.0563 & 0.3688 & 0.4250 \\
\hline 3 & OUTDOORCOMPOSTING & -0.1025 & 0.3275 & 0.4300 \\
\hline 4 & ANAEROBIC DIGESTION & -0.1650 & 0.2863 & 0.4512 \\
\hline 5 & TRANSPORTATIONTO THEMAINLAND & -0.3525 & 0.2412 & 0.5938 \\
\hline
\end{tabular}

Figure 4 shows the complete ranking, indicating that the alternatives are divided into three groups.

Erceg, O, Margeta, J 


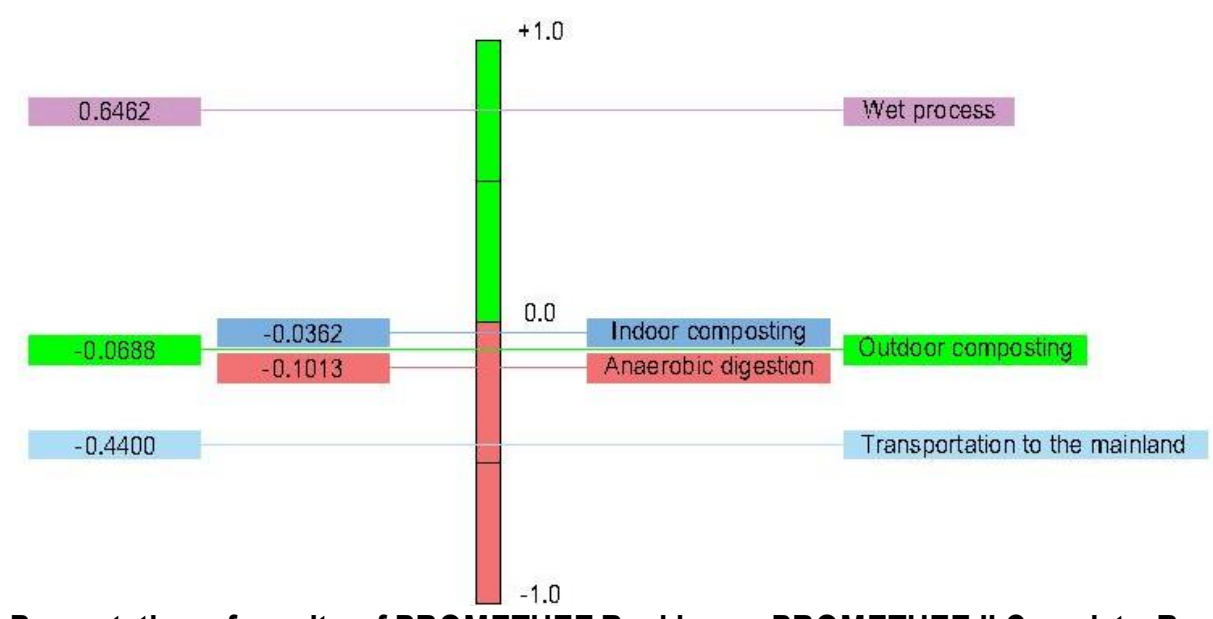

Figure 4 Presentation of results of PROMETHEE Rankings - PROMETHEE II Complete Ranking

The wet process, with a positive Phi, is the first-ranked technology, and transport to the mainland is the fifthranked technology. Three mutually compatible technologies, indoor composting, outdoor composting, and anaerobic digestion, could be further studied if necessary. The results are clearly visible, highlighting the advantages of the solutions and the relation between them. Three possible strategies were established to give decision-makers a clear choice for a compromise solution.

A sensitive analysis is necessary to determine the order's strength and the correctness of the decision, and it is an essential technique used to determine the robustness of the results. The program package has a built-in program, "Walking weights," that changes the order due to weight changes that can be directy monitored. This program helps to make decisions and accept solutions. The results indicate how different relative weights for the criteria's hierarchy will influence the final choice. In this regard, a multi-criteria analysis, including various percentage values for the preferences, was performed. The solution was first analyzed using the same percentage values for all criteria. Furthermore, the percentage for one group was then increased by $100 \%$, while all other groups remained the same $(4 \times 11.5 \%+1 \times 34 \%)$. A total of six preference value groups were analyzed. The results of the analysis are shown in Figure 5.

Aspects of emphasised preferences - the importance of the impacts (Phi)
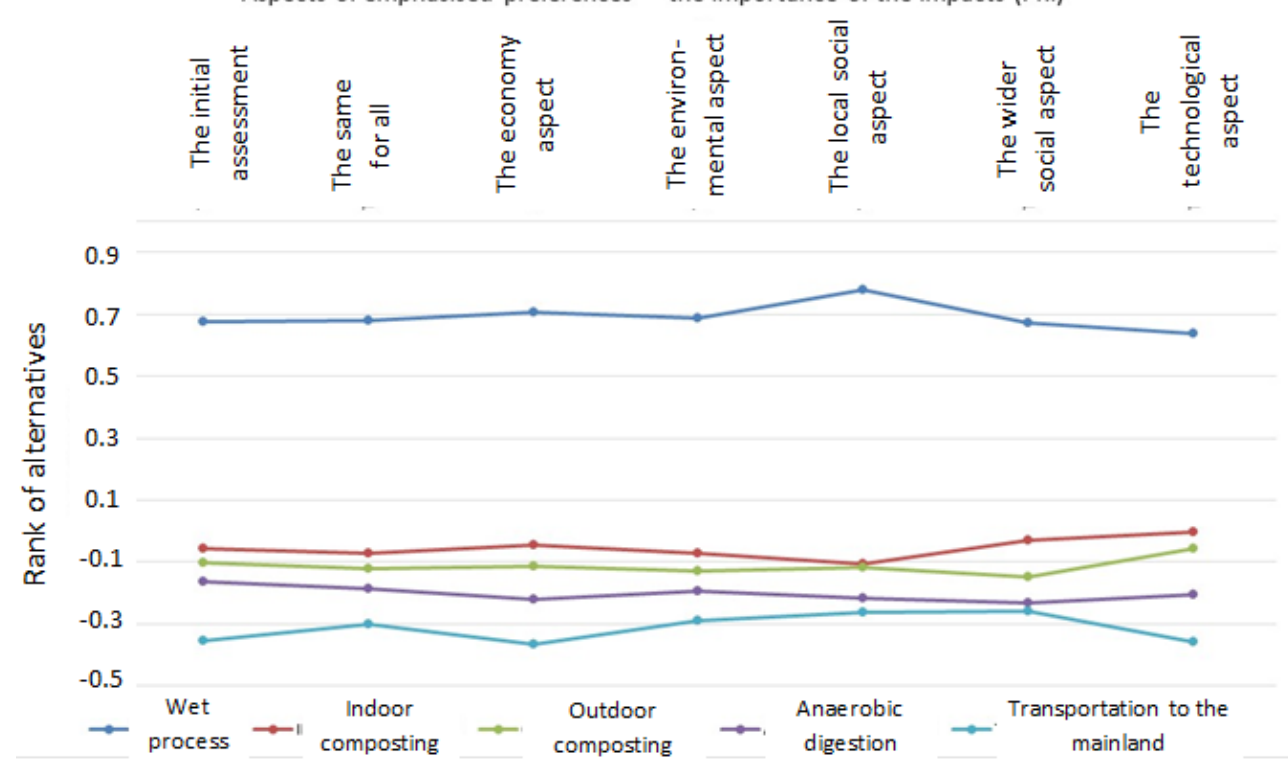

Figure 5 Graphical display of analysis results of the impact of weightings on the ranking of alternatives

(Phi result PROMETHEE Flow Table)

The order obtained is quite stable. The best choice is the wet process, while the worst option is the transport to the mainland in all the preference combinations. It can be concluded with great certainty that the wet procedure option has been rated as the best.

Erceg, O, Margeta, J 
The results can also be displayed in a different form using the GAIA option (Geometrical Analysis for Interactive Aid) in the program package to analyze the differences between options. The idea behind this method is to twist the multidimensional problem into two dimensions to allow a flat presentation (Figure 6).

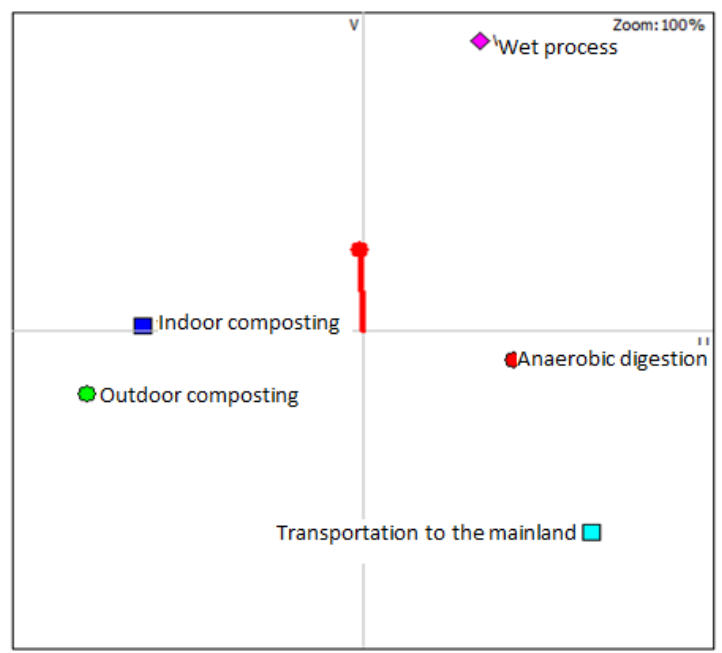

Figure 6 Presentation of results by GAIA Visual Analysis

The criteria in GAIA planes are shown as the axes drawn from the plane centers. The orientation of these axes is important because it shows how many criteria are related to each other. Criteria with similar preferences have axes close to each other, and conflicting criteria have axes that are in different directions. The length of the criterion axis is equally important, representing discrimination of criterion in relation to the others. The model and graphical interpretations of the results significantly contribute to the stakeholders' participation and understanding of the issues. With this kind of analysis, a reliable and credible decision can be made democratically. It follows that a local management strategy is far better for the islands than a regional strategy while respecting the Circular Economy's requirements.

\section{CONCLUSION}

In the presented preliminary study, a multi-criteria decision-making approach based on technical, economic, environmental, and social criteria is identified as a useful evaluation method for suitable food waste management options for small islands. Islands are a natural, cultural, and socioeconomic environment with a sensitive awareness of sustainability. Without applying the methodology presented, local stakeholders would find it difficult to support the proposed solution, even when present well. There is always doubt that there are other interests behind a novel proposed solution. The PROMETHEE method has proved to be useful in solving such problems. The method and the available software package enable the equitable treatment of numerically measurable and non-measurable criteria and technologically specific options. Additionally, the graphical presentation of the results and the relationship between the technically diverse options are easily understandable. The method's built-in sensitive analysis has been demonstrated as especially useful for the choice of solutions, particularly when the numerical data of an option are clearly preferable to others.

The results have shown that the application of the wet process could be the appropriate solution for food waste management for the island's sensitive natural and socioeconomic environment. The integration of food waste with the wastewater system is a practical solution for small islands lacking knowledge, equipment, and workforce. This option contains an entirely closed system with a small-scale environmental impact on the households and settements. Furthermore, it is an excellent solution for overcoming the seasonal variation in waste generation and treating the sludge at the wastewater treatment plant. It is the best option when considering the storage, collection, transport costs, and associated environmental impacts, as well as the recirculation of nutrients and weight and volume reduction. The overall problem of food waste on the island is solved by the treatment of organic waste from the WWTP using composting. Composting is a traditional method of disposal of organic waste that is technologically simple and economically and ecologically acceptable, especially for the smaller seasonal generation of waste on Erceg, O, Margeta, J 
Vis. Furthermore, the preconditions are made for returning the nutrients into the food chain. Using the compost on a nutrient-poor island supports a sustainable livelihood and contributes to the fulfillment of the objectives of the Circular Economy.

Acknowledgements: This paper is based on work primarily supported by the Croatian Scientific Foundation under HRZZ Research Project IP-11-2013-9852.

\section{References}

[1] EC, 2015 - European Commission (2015a) Towards a circular economy. New package released on December 2nd, 2015. All documents including in the package are available online at http://ec.europa.eu/environment/circular economyl. Access 24 January 2019.

[2] EEC, 1991:Council Directive 91/271/EEC of 21 March 1991concerning urban waste-water treatment (amended by the 98/15/EC of 27 February 1998).

[3] Papargyropolou, E.; Lozan, R.; Steinberg, J.K.; Wright, N. 2014: The food waste hierarchy as a framework for the management of food surplus and food waste, Journal of Cleaner Production, 76, pp. 106-115. https://doi.org/10.1016/j.jdepro.2014.04.020

[4] ISO 14040:2006: International Standard - Environmental management - Life cycle assessment - Principles and framework. International Organization for Standardization, Geneva, Switzerland.

[5] Manfredi S.; Cristobal J.; Torres de Matos C.; Giavini M.; Vasta M.; Sala S.; Saouter, E.; Tuomisto, H. 2015: Im proving Sustainability and Circularity of European Food Waste Managementwith a Life Cycle Approach, JRC Technical Reports. https://core.ac.uk/download/pdf/38631666.pdf. (Accessed 25 January 2018)

[6] Thomsen, M.; Romeo, D.; Caro, D.; Seghetta, M.; Cong, R.-G. 2018: Environmental-economic analysis of integrated organic waste and wastewater management systems: A case study from Aarhus City (Denmark), Sustainability, 10 (10), pp.1-20, https://doi.org/10.3390/su10103742

[7] Victoria St. Martin (2015) LITERATURE OVERVIEW Impacts of Disposers and Food Waste Management http://mww.insinkerator.jp/information/45/2015-Food_Waste_Disposer_Environmental_Impact.pd. (Accessed 15 February 2017)

[8] Solanyi, C. T.; Juan, P. R. M.; Cesar, A.; Garcia, U. 2016: Optimization Models of Organic Solid Waste: Review Article, International Journal of Environmental Protection, 6 (1), pp. 138-147. https://doi.org/10.5963//JEP0601016

[9] Goulart Coelho, L. M.; Lange, L. C.; Coelho, H. M. 2017: Mult-criteria decision making to support waste management A critical review of current practices and methods, Waste Management \& Research, 35 (1), pp. 3-28. https://doi.org/10.1177/0734242X16664024

[10] Wang, J.J.; Jing, Y.-Y.; Zhang, C.-F.; Zhao, J.-H. 2009: Review on multi-criteria decision analysis aid in sustainable energy decision-making. Renewable and Sustainable Energy Reviews, 13 (9), pp. 2263-2278, https://doi.org/10.1016/j.rser.2009.06.021

[11] Achillas, C.; Moussiopoulos, N.; Karagiannidis, A.; Banias, G.; Perkoulidis, G. 2013: The use of multi-criteria decision analysis to tackle waste management problems: a literature review, Waste Managementand Research, 31 (2), pp.115129, https://doi.org/10.1177/0734242X12470203

[12] Mareschal B.: Visual PROMETHEE Academic Edition 1.4.๑, 2014

[13] Gradina Vis d.o.o. http://gradinavis.hrl. (Accessed 10 January 2018)

[14] Margeta, J. 2017: Upravljanje krutim komunalnim otpadom, Sveučilište u Splitu, Fakultet građevinarstva, arhitekture i geodezije u Splitu (in Croatiann)

[15] Plan Croatia 2017-2022, Solid waste management Plan for Croatia 2017 - 2022, NN 3/17. https://narodnenovine.nn.hr/clanci/sluzbeni/full/2017_01_3_120.html. (Accessed 5 April 2018)

[16] Metcalf \& Eddy, Inc. 2003: Wastewater Engineering Treatmentand Reuse, McGraw Hill, New York.

[17] Brans, J.-P.; Vincke, P.; Mareschal, B. 1986: How to select and how to rank projects: The PROMETHEE method. European Journal of Operational Research, 24 (2), pp. 228-238. https://doi.org/10.1016/0377-2217(86)90044-5.

[18] Vego, G.; Kučar - Dragičević, S.; Koprivanac, N. 200: Application of multi-criteria decision making on strategic municipal solid waste management in Dalmatia, Croatia, Waste Management, 28, pp. 2192-2201. https://doi.org/10.1016/j.wasman.2007.10.002

[19] Brans, J.-P.; Vincke, P. 1985: Note - A preference ranking organisation method (The PROMETHEE Method for Multiple Criteria Decision-Making), Management science, 31 (6), pp. 647-656, https://doi.org/10.1287/mnsc.31.6.647

Please cite this article as:

Erceg, O.; Margeta, J.: Selection of food waste management option by PROMETHEE method, Electronic Journal of the Faculty of Civil Engineering Osijek-e-GFOS, 2019, 19, pp. 87-97, https://doi.org/10.13167/2019.19.9

Erceg, O, Margeta, J 